\title{
INFLUENCE OF MUNICIPAL SOLID WASTE COMPOST ON SOIL PROPERTIES AND PLANT REESTABLISHMENT IN PERI-URBAN ENVIRONMENTS
}

\author{
Gabriela Civeira $^{1^{*}}$
}

\begin{abstract}
Soils in urban areas often present characteristics that might submit these environments to erosion processes. Applying municipal solid wastes (MSW) composts to soils have been suggested as a means to improve physical and chemical properties. A field experiment with a completely randomized design was conducted in a Typic Argiudoll from a degraded area in Buenos Aires City. The objective was to evaluate the effect of MSW compost application on soil properties, residue decomposition and Poa (Poa pratensis L.) reestablishment. At the beginning of the trial, compost was prepared and applied in a bare soil on $0.25 \mathrm{~m}^{2}$ square plots afterwards litterbags were incorporated and Poa was sown. Compost amounts were: 0 (control); 2 (low); 4 (medium) and $7 \mathrm{~kg} \mathrm{~m}^{-2}$ (high) on fresh matter basis. During the trial residue decomposition and aerial dry matter (DM: g treatment ${ }^{-1}$ ) were evaluated, at the end soil physical and chemical parameters were measured. Medium and high compost rates increased organic $\mathrm{C}$, total $\mathrm{N}$ and extractable P. Addition of $2 \mathrm{~kg} \mathrm{~m}^{-2}$ affected soil organic $\mathrm{C}$ as well, but in a minor fee. Soil physical properties were improved after MSW compost addition. In medium and high doses, augmentations in organic matter reduced bulk densities and enhanced water infiltration. Aerial DM was significantly affected by treatments $(\mathrm{p}<0.05)$. Medium dose improved soil properties and plant DM in the same amount as the highest rate. MSW compost application in urban soils is a viable alternative, since allows the full restoration of an area with serious environmental problems.
\end{abstract}

Key words: soil restoration, municipal solid waste compost, soil properties.

\section{INTRODUCTION}

Soils intensively affected by human activities might present special features such as mixed horizons, foreign materials and thin topsoil (Short et al., 1986; Civeira and Lavado, 2008). Normally, these soils are poor in organic matter $(\mathrm{OM})($ e.g., $<1 \%)$ and fertility with reductions in their most important physical properties, such as structural stability and water retention. Eventually, these characteristics might have a detrimental effect on plant growth and submit this particular environment to erosion processes (Vetterlein and Hüttl, 1999; Scharenbroch et al., 2005). Consequently, deteriorated soils in populate cities do not tolerate agricultural or recreational uses and turned these environments into places with low probability of community progress.

${ }^{1}$ Instituto Nacional de Tecnología Agropecuaria (INTA), Centro Nacional de Investigación Agropecuaria (CNIA), Instituto de Suelos, Las Cabañas y De Los Reseros s/n (1712), Villa Udaondo, Castelar, Buenos Aires, Argentina. "Corresponding author (gciveira@cnia.inta.gov.ar).

Received: 19 October 2009.

Accepted: 24 February 2010.
Due to urban soils present different characteristics compared to agricultural ones, their intrinsic properties and rehabilitation techniques have not yet been sufficiently relieved (Larson and Pierce, 1991; Scharenbroch et al., 2005). In recent decades, the application of organic wastes from different origins (manure, sewage sludge and municipal organic wastes) to degraded soils is a practice globally accepted to recover, replenish and preserve $\mathrm{OM}$, fertility and vegetation (Vetterlein and Hüttl, 1999; Civeira and Lavado, 2008). Before application to soils, organic wastes should been stabilized using composting techniques. The use of composted organic wastes produces changes in soil physical, chemical and biological properties and can enhance plant growth after its application. However, the influence of $\mathrm{C}$ rich materials, like municipal organic wastes compost, on soil physical, chemical and biological properties depends upon several factors: amount and components of added organic materials, soil type and weather conditions (Unsal and Ok, 2001; Drozd, 2003). As pointed out by Giusquiani et al. (1995) and Drozd (2003) the use of composts from municipal solid wastes (MSW) improves the restoration of degraded soils and allows an appropriate final disposition 
of such materials, solving a major environmental and economical problem generated in the cities.

Considering that soil recovery in urban environments depends upon several factors, such as those mentioned above, the objective of this study was to study the response of an urban degraded soil to different MSW compost application rates, as an alternative to MSW disposal and soil recovery. As indicators of soil response physical (bulk density, soil moisture, and water infiltration) and chemical ( $\mathrm{pH}$, electrical conductivity, organic $\mathrm{C}$, total $\mathrm{N}$, and extractable $\mathrm{P}$ ) parameters were evaluated. Plant reestablishment (total DM) and residue decomposition rates were also measured in a field experiment in Buenos Aires city.

\section{MATERIALS AND METHODS}

\section{Compost preparation}

The MSW used in this study were obtained from local homeowners and a supermarket. These sources presented mixed organic domestic wastes (fruits and vegetables), including gardens and grass trimmings. The inorganic fraction was manually separated from the organic fraction. The MSW organic fraction were shredded and placed in a pile. The pile was thoroughly mixed every $2 \mathrm{~d}$, to ensure that all MSW were exposed to high temperatures. The pile was also watered every $4 \mathrm{~d}$ in order to maintain the aerobic and composting process in optimum conditions. Compost temperature was monitored every $10 \mathrm{~d}$ approximately with a mercury in-glass soil thermometer. Compost characterization is presented in Table 1.

\section{Site description and experimental design}

The field trial was laid out between January 2006 and June 2007 in Buenos Aires city ( $34^{\circ} 35^{\prime}$ S, 58 $26^{\circ}$ ' W). The climate is temperate with annual precipitation average varying between 900 and $1600 \mathrm{~mm}$ and annual mean temperature of $18{ }^{\circ} \mathrm{C}$. The experimental units were 0.25 $\mathrm{m}^{2}$ rectangle shape and established in a $3 \mathrm{~m}^{2}$ square. The soil was a Typic Argiudoll that presented no surface horizon and many foreign materials such as wood, glass and bricks, which were removed before the establishment of the experiment. Soil characteristics are presented in Table 2.

The MSW compost was used for a one-time application on the $0.25 \mathrm{~m}^{2}$ plots at the beginning of the trial, in the following doses: 0 (control); 2 (low); 4 (medium) and $7 \mathrm{~kg} \mathrm{~m}^{-2}$ (high) on a fresh matter basis. Compost was surface-applied with rakes to bare soil and seeds of Poa were subsequently sown. The treatments were assigned in a completely randomized design to each experimental unit and were carried out in three replicates
Table 1. Characteristics of municipal solid wastes compost. (Dry basis).

\begin{tabular}{lc}
\hline $\mathrm{pH}$ & 6.82 \\
Electrical conductivity, dS m & -1 \\
Organic C, $\mathrm{g} \mathrm{kg}^{-1}$ & 1.98 \\
Total N, $\mathrm{g} \mathrm{kg}^{-1}$ & 23.5 \\
$\mathrm{C}: \mathrm{N}$ ratio & 0.15 \\
Extractable $\mathrm{P}, \mathrm{mg} \mathrm{kg}^{-1}$ & 156.6 \\
\hline
\end{tabular}

Table 2. Soil characteristics in the urban site.

\begin{tabular}{lc}
\hline $\mathrm{pH}$ & 6.56 \\
Electrical conductivity, dS m & -1 \\
Organic C, $\mathrm{g} \mathrm{kg}^{-1}$ & 2.15 \\
Total N, $\mathrm{g} \mathrm{kg}^{-1}$ & 16.18 \\
Extractable P, mg kg-1 & 0.95 \\
Bulk density, $\mathrm{g} \mathrm{cm}^{-3}$ & 12.38 \\
Infiltration, $\mathrm{cm} \mathrm{h}^{-1}$ & 1.52 \\
Moisture, \% & 75 \\
\hline
\end{tabular}

(12 experimental plots). Soil physical and chemical properties were measured twice, at the beginning and at the end of the experiment. Three composite soil samples were taken from each plot at depths of 0 to 20 $\mathrm{cm}$ with a $5 \mathrm{~cm}$ diameter bucket auger in January 2006 (before treatment), and then again in June 2007. The following soil analyses were carried out in soil samples: Organic C content, by ashing; total Kjeldahl N (total N) by the Kjeldahl method (Bremner, 1960); available P by the Bray and Kurtz method (Bray and Kurtz, 1945) (extractable P); electrical conductivity (EC) in soil extracts and $\mathrm{pH}$ in water $(1: 2.5)$. Bulk density (BD) was measured by the core method; water infiltration (INF) by a variation of the USDA-NRCS method (1999) and soil moisture by the gravimetrically method. MSW compost was analyzed by the same methods as for the soil samples for organic $\mathrm{C}$, total $\mathrm{N}$, available $\mathrm{P}, \mathrm{EC}$ and $\mathrm{pH}$. Poa aerial DM for each treatment was measured in order to compare MSW compost effects on planted vegetation during the experiment. Plant cuttings were performed 14 times to a residual height of $5 \mathrm{~mm}$ for all treatments. Plant samples were collected, dried at $70{ }^{\circ} \mathrm{C}$ for $48 \mathrm{~h}$ and weighed to obtain total aerial DM data for each treatment.

\section{Plant residue decomposition sampling and analysis}

In order to evaluate plant residue decomposition in the soil, litterbags, $20 \times 20 \mathrm{~cm}$, were constructed of transparent nylon containers with a $2 \mathrm{~mm}^{2}$ mesh size, following the method used by Lachnicht et al. (2004). Twenty-five grams of Poa shoots were placed into each litter bag and then incorporated on the upper soil layer (10 
$\mathrm{cm}$ ) of each experimental unit and its replications before sowing. During the trial each litterbag was unburied and weighed on seven different dates $0,30,60,90,120,150$ and $180 \mathrm{~d}$. Decomposition rates were calculated dividing litterbags weight in each sampling date $(\mathrm{g})$ and days the litterbag remained in the soil between each sampling date $(30 \mathrm{~d})$.

\section{Statistical analysis}

The experimental data from each treatment were subjected to ANOVA and means were compared by tests of least significant differences (LSD), at the confidence level of $\mathrm{p}<0.05$. The statistical software used was INFOSTAT (2002).

\section{RESULTS AND DISCUSSION}

\section{Compost process and general characteristics}

The compost pile reached the thermophile $\left(>45^{\circ} \mathrm{C}\right)$ phase rapidly $10 \mathrm{~d}$ after its establishment (Figure 1). Elevated temperatures lasted approximately $20 \mathrm{~d}$ and descended to lower values $\left(<30^{\circ} \mathrm{C}\right)$ in the subsequent weeks, showing a typical biodegradation curve. These temperatures corresponded to optimum biological activity (around $40{ }^{\circ} \mathrm{C}$ ). Once the pile achieved the thermophile phase pathogens inside the residues were considered eliminated as discerned in the literature (Tognetti et al., 2007; Weber et al., 2007). Values of the $\mathrm{C} / \mathrm{N}$ ratio indicated an advanced maturity stage, as a result a stabilized and quality compost was obtained (Hassen et al., 2001, Eggen and Vethe, 2001). Least duration of thermophilic phase (close $4 \mathrm{wk}$ ) indicates a normally extended decomposition and a rapid transition to the stabilization stage (Zucconi and De Bertoldi, 1987). After 3-mo stabilization phase was over and compost was ready for soil application.

Compost organic C content (Table 2) was elevated and similar to values (20 and 55\%) cited by other authors (Grigatti et al., 2004; Weber et al., 2007). Based on literature data, total $\mathrm{N}$ content (Table 2) was low for

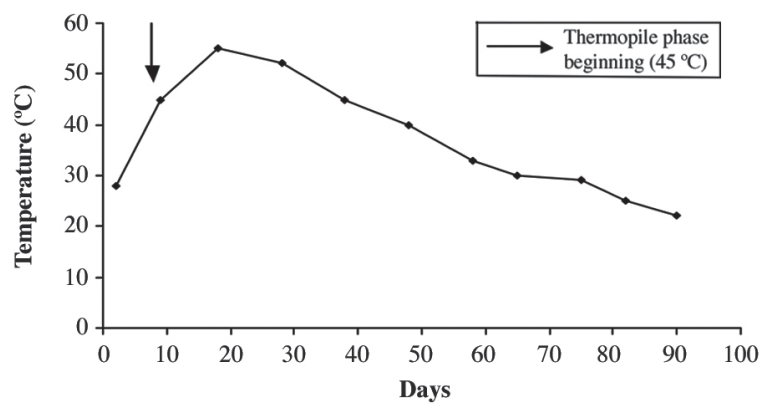

Figure 1. Temperature during municipal solid wastes composting. this type of compost (Tognetti et al., 2007). Zucconi and De Bertoldi (1987) observed low total N contents in composts due to ammonia volatilization and related them with elevated temperatures during composting process. In our case, ambient temperatures were superior to $35{ }^{\circ} \mathrm{C}$ during composting period (data not shown) so $\mathrm{N}$ volatilization could have taken place. The final $\mathrm{C} / \mathrm{N}$ ratio (Table 2) was elevated, probably due to $\mathrm{N}$ loss by ammonia volatilization favored with high temperatures. In addition, wastes included in the compost were fruits, vegetables and grass clippings normally with high $\mathrm{C} / \mathrm{N}$ ratio, which also favoured microbial $\mathrm{N}$ immobilization. These particular characteristics could have raised final $\mathrm{C} / \mathrm{N}$ ratio more than expected values. If compared with other composts, which usually contain less than $10 \mathrm{mg}$ $\mathrm{kg}^{-1}$ of extractable $\mathrm{P}$, this compost should be classified as relatively high in available P. The obtained MSW compost was no saline and neutral, values of $\mathrm{pH}$ and $\mathrm{EC}$ achieved at $90 \mathrm{~d}$ were within the range acceptable for plant growth recommended by Rynk (1992; 2003), and similar to other reported for MSW composts (Cooperband and Middleton, 1996).

\section{Soil chemical and physical properties}

Chemical properties (Table 3) showed a high response after the MSW compost addition to soil. Compost application positively affected total $\mathrm{N}$ content in soils. The LSD test revealed a significant difference $(\mathrm{p}<$ 0.05 ) for doses of $2 \mathrm{~kg} \mathrm{~m}^{-2}$ upwards. Organic $\mathrm{C}$ was also affected by MSW compost addition: Higher values of organic $\mathrm{C}$ were observed in low, medium and higher doses of compost, the highest levels were observed for 4 and $7 \mathrm{~kg} \mathrm{~m}^{-2}$. Nevertheless, the soil organic $\mathrm{C}$ was not explained by the quantity of compost applied. Extractable $\mathrm{P}$ was also increased in soils with significant differences between control and the other treatments: medium and high doses presented the greatest increase in extractable $\mathrm{P}$ in soils (Table 3). Some authors observed that MSW compost effectively supply $\mathrm{P}$ to soil with $\mathrm{P}$ concentration increasing with increasing application rates (IglesiasJiménez and Álvarez, 1993). They also reported that MSW composts provided equivalent amounts of $\mathrm{P}$ to soil as mineral fertilizers.

The $\mathrm{C} / \mathrm{N}$ ratio showed a difference due to $\mathrm{MSW}$ compost application. The LSD procedure revealed a significant increase with higher doses of MSW compost ( $\mathrm{p}$ $<0.05$ ). The highest levels were observed for 4 and $7 \mathrm{~kg}$ $\mathrm{m}^{-2}$. As expected, MSW compost application consistently increased soil $\mathrm{OM}$ and soil $\mathrm{C} / \mathrm{N}$ ratio to levels greater than not amended ones (Crecchio et al., 2004; Walter et al., 2006).

Compost additions affected soil $\mathrm{pH}$; medium and high doses raised $\mathrm{pH}$ from 6.5 to 6.9. Tognetti et al. (2007) 
Table 3. Changes in soil chemical and physical properties after compost application.

\begin{tabular}{lccrr}
\hline & \multicolumn{3}{c}{ Treatments } \\
\cline { 2 - 4 } & $\mathbf{0}$ & $\mathbf{2}$ & $\mathbf{4}$ & $\mathbf{7}$ \\
\cline { 2 - 4 } $\mathrm{pH}$ & $6.51 \mathrm{a}$ & $6.62 \mathrm{a}$ & $6.90 \mathrm{~b}$ & $6.95 \mathrm{~b}$ \\
Electrical conductivity, dS m${ }^{-1}$ & $2.15 \mathrm{a}$ & $2.21 \mathrm{a}$ & $2.22 \mathrm{a}$ & $2.22 \mathrm{a}$ \\
Organic C, $\mathrm{g} \mathrm{kg}^{-1}$ & $16.12 \mathrm{a}$ & $18.52 \mathrm{~b}$ & $21.35 \mathrm{c}$ & $22.23 \mathrm{c}$ \\
Total N, g kg-1 & $0.95 \mathrm{a}$ & $0.98 \mathrm{a}$ & $1.05 \mathrm{~b}$ & $1.12 \mathrm{~b}$ \\
Extractable P, mg kg-1 & $12.32 \mathrm{a}$ & $13.50 \mathrm{a}$ & $17.95 \mathrm{~b}$ & $18.52 \mathrm{~b}$ \\
C:N ratio & $16.94 \mathrm{a}$ & $17.5 \mathrm{a}$ & $20.93 \mathrm{~b}$ & $21.04 \mathrm{~b}$ \\
Bulk density, $\mathrm{g} \mathrm{cm}^{-3}$ & $1.52 \mathrm{a}$ & $1.45 \mathrm{~b}$ & $1.32 \mathrm{c}$ & $1.31 \mathrm{c}$ \\
Infiltration, $\mathrm{cm} \mathrm{h}^{-1}$ & $78 \mathrm{a}$ & $84 \mathrm{~b}$ & $90 \mathrm{c}$ & $92 \mathrm{c}$ \\
Moisture, $\%$ & $41 \mathrm{a}$ & $58 \mathrm{~b}$ & $71 \mathrm{c}$ & $77 \mathrm{c}$ \\
\hline
\end{tabular}

Means followed by the same letter in the same row do not differ $(\mathrm{p}<0.05)$.

informed soil $\mathrm{pH}$ increases when mature composts were applied. However, changes in $\mathrm{pH}$, like in this case, were not always proportional to doses.

In the present study, organic $\mathrm{C}$, total $\mathrm{N}$ and extractable $\mathrm{P}$ increased with MSW compost application, significant increases were observed for 4 and $7 \mathrm{~kg} \mathrm{~m}^{-2}$ doses. Application of $2 \mathrm{~kg}$ compost $\mathrm{m}^{-2}$ affected soil organic C as well, but in a minor extent. In addition, a significant positive correlation was identified between organic $\mathrm{C}$ and soil $\mathrm{N}$ and $\mathrm{P}$ content for medium and higher compost doses $\left(\mathrm{R}^{2}=0.91 ; \mathrm{p}<0.05\right.$ and $\mathrm{R}^{2}=0.89 ; \mathrm{p}<0.05$, respectively). It should be considered that a lower application rate could be affecting nutrient availability, plant development and soil restoration. There was no significant difference between applying medium or high compost dose (Table 3). As pointed out by other authors, increasing compost application rates not always augmented organic $\mathrm{C}$ and nutrients contents (like total $\mathrm{N}$ and extractable $\mathrm{P}$ ) in soils (among others, Giusquiani et al., 1995; Barzegar et al., 2002). Limited organic $C$ and nutrients after addition of much higher rates of composted MSW have been attributed to rapid mineralization of labile organic matter (Flavel and Murphy, 2006).

Soil physical properties, in a similar way to chemicals, were also improved after MSW compost addition. MSW compost application tended to reduce $\mathrm{BD}$ at the end of the experiment (Table 3). By the final sampling date treatments with medium dose and high dose (4 and 7 $\mathrm{kg} \mathrm{m}^{-2}$, respectively) had significantly lower $(\mathrm{p}<0.05)$ bulk densities than the control and the low dose treatment as well The decrease in BD appears to have been due to dilution of the denser mineral fraction by the less dense MSW compost doses. These results are in line with Haynes and Naidu (1998) and Civeira and Lavado (2006) who reported that lighter compost particles might penetrate the soil matrix and eventually decrease bulk densities.

Soil moisture and water infiltration were significantly affected by MSW compost additions at the end of the experiment $(\mathrm{p}<0.05)$ (Table 3$)$. Medium and high compost doses ( 4 and $7 \mathrm{~kg} \mathrm{~m}^{-2}$, respectively) showed the maximum soil moisture and water infiltration rates compared to control and $2 \mathrm{~kg} \mathrm{~m}^{-2}$. An increase of water infiltration and moisture should be considered a consequence of total porosity augmentation in soils after MSW composts application (Weber et al., 2007). Although, it is commonly mentioned that compost improve physical conditions particularly water holding capacity studies on soil moisture change are scarce. In some cases, compost and other organic wastes did not increase soil moisture. This result was probably due to augmentations in plant cover and water utilization in compost-amended soils (Giusquiani et al., 1995; Cooperband, 2000; Meyer et al., 2001). Despite of that, in the present study the MSW compost penetrated the soil surface and improved measured physical properties: BD, moisture retention and water infiltration (Table 3) (Risse and Faucette, 2001).

\section{Plant aerial dry matter}

Poa pratensis sp. total aerial DM (g DM treatment $\left.{ }^{-1}\right)$ was significantly affected by treatments $(\mathrm{p}<0.05)$ (Figure 2$)$. Medium and high doses $\left(4\right.$ and $7 \mathrm{~kg} \mathrm{~m}^{-2}$ ) accumulated about two times more aerial biomass than control treatment. No significant differences were observed between 4 and 7 $\mathrm{kg} \mathrm{m}^{-2}$ doses $(\mathrm{p}>0.05)$. Improvements in plant biomass have been reported elsewhere (Zhang et al., 2000; GarciaGomez et al., 2002), mainly due to compost effects on nutrients availability in soils. In the present study, despite the low total $\mathrm{N}$ content in MSW compost, medium and high doses provided adequate $\mathrm{N}$ for plant growth and 


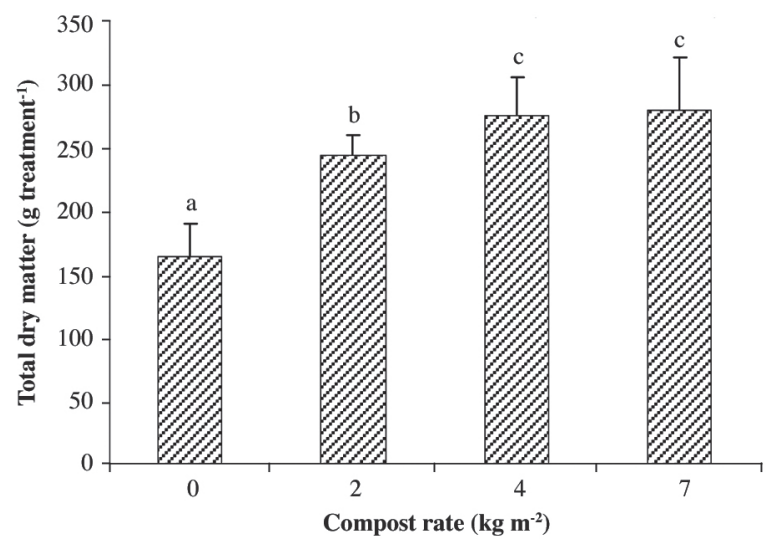

Different letters indicate differences among estimated treatment means at the 0.05 probability level.

Values are means with standard error as error bars.

Figure 2. Poa pratensis sp. total dry matter $\left(\right.$ g treatment $\left.^{-1}\right)$ as affected by compost doses.

support. Therefore, some studies (Iglesias-Jiménez and Alvarez, 1993; Mylavarapu and Zinati, 2009) suggested that elevated doses of MSW compost increase inorganic N forms and also provide a consistent nutrient supply during the initial growing season and could meet subsequent plant demand. At the end of the experiment, higher and medium MSW compost doses exhibited higher organic $\mathrm{C}$, nutrients contents and superior physical properties in the topsoil. As expected, these better soil conditions in the plots where MSW compost were applied resulted in higher shoot growth.

\section{Residue decomposition}

Plant residue decomposition from the $1^{\text {st }}$ month until the $4^{\text {th }}$ month showed significant differences among treatments $(\mathrm{p}<0.05)$ (Figure 3$)$. The addition of 4 and $7 \mathrm{~kg}$ compost $\mathrm{m}^{-2}$ increased two times residue decomposition compared to control and $2 \mathrm{~kg} \mathrm{~m}^{-2}$ dose. After 4-mo residue decomposition showed similar trends and presented no significant differences between treatments $(\mathrm{p}<0.05)$. The size of the pores of the litterbags $(2 \mathrm{~mm})$ limited accessibility of the residues to larger invertebrates so the

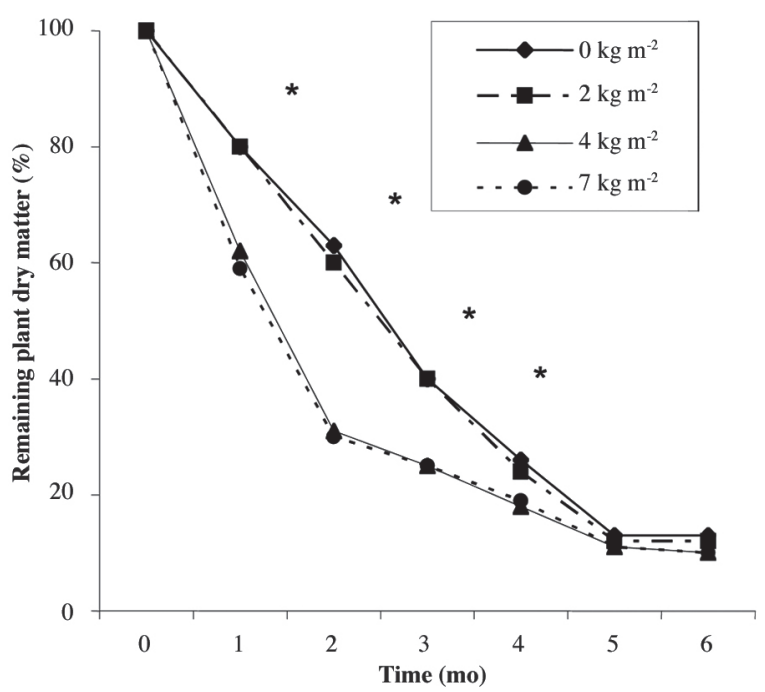

An asterisk indicates differences among treatments for the same time $(\mathrm{p}<0.05)$.

Figure 3. Plant residue decomposition as remaining plant dry matter in bags. Results are means of three replicates.

observed breakdown of the residues could primarily be attributed to microorganisms and smaller invertebrates Treatments with MSW compost addition raised plant residue decomposition more than control treatment in the first months. This was probably, because of augmentations in soil microbial biomass activity and $\mathrm{C}$ mineralization during this initial stage (Giusquiani et al., 1995; Bhattacharyya et al., 2003; Crecchio et al., 2004).

Plant decomposition rates were significantly different between treatments $(\mathrm{p}<0.05)$ in the first three sampling dates (Table 4). Increasing compost application to soils, augmented decomposition: medium and high doses (4 and $7 \mathrm{~kg}$ compost $\mathrm{m}^{-2}$ ) presented maximum decomposition rates compared with control and $2 \mathrm{~kg}$ compost $\mathrm{m}^{-2}$. All treatments showed the highest values at the beginning, and the lowest ones, at the end of the assay. Subsequently the initially superior decomposition rates, a moderate decrease in all treatments was observed previously

Table 4. Mean decomposition rates of plant residue as affected by compost application rates at different sampling times.

\begin{tabular}{lllllll}
\hline & \multicolumn{7}{c}{ Decomposition rates } \\
\cline { 2 - 7 } Treatments & $\mathbf{3 0 ~ d}$ & $\mathbf{6 0 ~ d}$ & $\mathbf{9 0 ~ d}$ & $\mathbf{1 2 0} \mathbf{~ d}$ & $\mathbf{1 5 0 ~ d}$ & $\mathbf{1 8 0 ~ d}$ \\
\hline $\mathrm{kg} \mathrm{m}^{-2}$ & $0.17 \mathrm{a}$ & $0.14 \mathrm{a}$ & $0.18 \mathrm{a}$ & $0.11 \mathrm{a}$ & $0.11 \mathrm{a}$ & $0.00 \mathrm{a}$ \\
0 & $0.17 \mathrm{a}$ & $0.16 \mathrm{a}$ & $0.17 \mathrm{a}$ & $0.12 \mathrm{a}$ & $0.10 \mathrm{a}$ & $0.00 \mathrm{a}$ \\
2 & $0.32 \mathrm{~b}$ & $0.25 \mathrm{~b}$ & $0.05 \mathrm{~b}$ & $0.06 \mathrm{~b}$ & $0.06 \mathrm{~b}$ & $0.01 \mathrm{a}$ \\
4 & $0.34 \mathrm{~b}$ & $0.24 \mathrm{~b}$ & $0.04 \mathrm{~b}$ & $0.05 \mathrm{~b}$ & $0.05 \mathrm{~b}$ & $0.01 \mathrm{a}$ \\
7 & &
\end{tabular}

Means followed by the same letter in the same column do not differ $(\mathrm{p}<0.05)$. 
becoming constant. Plant decomposition rates became constant earlier in 4 and $7 \mathrm{~kg} \mathrm{~m}^{-2}$ doses than in control and $2 \mathrm{~kg} \mathrm{~m}^{-2}$ (Table 4). Microbial population of this soil, as well as its residue decomposition, depends mainly on the amount and type of compost applied (Bhattacharvya et al., 2003; Crecchio et al., 2004).

\section{CONCLUSIONS}

MSW compost addition on this degraded soil recovered plant growth, raised residue decomposition, and improved physical and chemical properties. As expected, organic matter increased after MSW compost application. Superficial $(0-20 \mathrm{~cm})$ organic $\mathrm{C}$ augmentation enhanced properties and played a fundamental role in the recovery of the topsoil, allowing the improvement of the surrounding environment. There were no significant differences between applying medium dose and high dose to soil. Possibly, an optimum application threshold was reached; beyond that, higher levels of compost doses would not considerably increase soil restoration. However, application rates should be appropriately adjusted in order to minimize detrimental effects and environmental problems. The results of this study showed that the use of MSW compost in this type of soils is an accurate alternative, since provides a nearby available source of nutrients and allows the full recovery of a severe damaged ecosystem with critical environmental problems.

\section{RESUMEN}

Efecto de la aplicación de compost de residuos sólidos municipales sobre las propiedades de los suelos y el establecimiento de plantas en ambientes peri-urbanos. Los suelos de las áreas urbanas presentan características que pueden someter estos ambientes a procesos erosivos. La aplicación de composts de residuos sólidos urbanos (MSW) a los suelos es una práctica que mejora sus propiedades. El objetivo del trabajo fue evaluar el efecto del compost de MSW sobre las propiedades, la descomposición de residuos y el restablecimiento de la especie Poa (Poa pratensis L.) en estos suelos. En un Argiudol típico degradado de la ciudad de Buenos Aires se realizó un ensayo con diseño completamente aleatorizado. Se preparó e incorporó compost en parcelas de $0,25 \mathrm{~m}^{2}$ en las siguientes cantidades: 0 (testigo); 2 (baja); 4 (media) y $7 \mathrm{~kg} \mathrm{~m}^{-2}$ (alta), se enterraron bolsas de descomposición y posteriormente se sembró Poa. Periódicamente se evaluaron la tasa de descomposición de residuos y la materia seca (MS) aérea y al finalizar las propiedades físicas, y químicas. Las dosis media y alta de compost aumentaron el C orgánico, $\mathrm{N}$ total y Pextractable. La adición de $2 \mathrm{~kg} \mathrm{~m}^{-2}$ afectó el $\mathrm{C}$ orgánico en menor medida. Las propiedades físicas mejoraron con la adición del compost, el aumento de la materia orgánica redujo la densidad aparente y mejoró la infiltración en las dosis media y alta. La MS fue afectada por los tratamientos. La dosis media mejoró las propiedades de los suelos y los niveles de MS en el mismo nivel que la dosis alta. La aplicación de compost de MSW en suelos urbanos es una alternativa para recuperar áreas con problemas ambientales.

Palabras clave: Restauración suelos, compost, residuos sólidos urbanos, propiedades físicas y químicas.

\section{LITERATURE CITED}

Barzegar, A.R., A. Barzegar, M. Yousefi, and A Daryashenas. 2002. The effect of addition of different amounts and types of organic materials on soil physical properties and yield of wheat. Plant and Soil 247:295-301.

Bhattacharyya, P., K. Chakrabarti, and A. Chakraborty. 2003. Effect of MSW compost on microbiological and biochemical soil quality indicators. Compost Science \& Utilization 11:220-227.

Bray, R.H., and L.T. Kurtz. 1945. Determination of total, organic and available forms of phosphorus in soils. Soil Science 59:39-46.

Bremner, J.M. 1960. Determination of nitrogen in soil by the Kjeldahl method. Journal of Agricultural Science 55:11-33.

Civeira, G., and R.S. Lavado. 2006. Organic matter addition effect on some hydrological properties in a degraded urban soil. Ciencia del Suelo 24:123-130.

Civeira, G., and R.S. Lavado. 2008. Nitrate losses, nutrients and heavy metal accumulation from substrates assembled for urban soils reconstruction. Journal of Environment Management 88:1619-1623.

Cooperband, L. 2000. Sustainable use of by products in land management. In Bartels, J.M., and W.A. Dick (eds.) Land application of agricultural, industrial and municipal by products. SSSA Book Series 6. p. 215235. Soil Science Society of America SSSA, Madison, Wisconsin, USA.

Cooperband, L.R., and J.H. Middleton. 1996. Changes in chemical, physical and biological properties of passively-aerated composted poultry litter and municipal solid waste compost. Compost Science \& Utilization 4: 24-34.

Crecchio, C., M. Curci, M. Pizzigallo, P. Ricciuti, and P. Ruggiero. 2004. Effects of municipal solid waste compost amendments on soil enzyme activities and bacterial genetic diversity. Soil Biology \& Biochemistry 36:1595-1605. 
Drozd, J. 2003. The risk and benefits associated with utilizing composts from municipal solid waste (MSW) in Agriculture. p. 211-226. In Lynch, J.M., J.S. Schepers, and I. Unver (eds.) Innovative soilplant systems for sustainable agricultural practices. Organisation for Economic Co-operation and Development (OECD), Paris, France.

Flavel, T., and V. Murphy. 2006. Carbon and nitrogen mineralization rates after application of organic amendments to soil. Journal of Environmental Quality 35:183-193.

Eggen, T., and O. Vethe. 2001. Stability indices for different composts. Compost Science \& Utilization 9:27-37.

Garcia-Gomez, A., M.P. Bernal, and A. Roig. 2002. Growth of ornamental plants in two composts prepared from agroindustrial wastes. Bioresource Technology 83:81-87.

Giusquiani, P.L., M. Pagliai, G. Gigliotii, D. Businelli, and A Benetti. 1995. Urban waste compost: Effects on physical, chemical and biochemical soil properties. Journal of Environmental Quality 24:175-182.

Grigatti, M., C. Ciavatta, and C. Gessa. 2004. Evolution of organic matter from sewage sludge and garden trimming during composting. Bioresource Technology 91:163-169.

Hassen, A., K. Belguith, N. Jedidi, A. Cherif, M. Cherif, and A. Boudabous. 2001. Microbial characterization during composting of municipal solid waste. Bioresource Technology 80:217-225.

Haynes, R.J., and R. Naidu. 1998. Influence of lime, fertilizer and manure applications on soil organic matter content and soil physical conditions: A review. Nutrient Cycling in Agroecosystems 51:123-137.

Iglesias-Jimenez, E., and C. Alvarez. 1993. Apparent availability of nitrogen in composted municipal refuse. Biology and Fertility of Soils 16:313-3168.

INFOSTAT. 2002. Professional version 1.1. Universidad Nacional de Córdoba, Estadística y Diseño, Facultad de Ciencias Agropecuarias, Ciudad Universitaria, Argentina.

Lachnicht, S.L., P. Hendrix, R. Potter, D.C. Colemana, and D.A. Crossley, Jr. 2004. Winter decomposition of transgenic cotton residue in conventional-till and notill systems. Applied Soil Ecology 27:135-142.

Larson, W.E., and F.J. Pierce. 1991. Conservation and enhancement of soil quality. p. 175-203. In Evaluation for sustainable land management in the developing world. International Board Soil Research Management, Bangkok, Thailand.
Meyer, V.F., E.F. Redente, K.A. Barbarick, and R. Brobst. 2001. Biosolids applications affect runoff water quality following forest fire. Journal of Environmental Quality 30:1528-1532.

Mylavarapu, R.S., and G.M. Zinati. 2009. Improvement of soil properties using compost for optimum parsley production in sandy soils. Scientia Horticulturae 120: 426-430.

Risse, L.M., and B. Faucette. 2001. Compost utilization for erosion control. University of Georgia Cooperative Extension Service Bulletin 1200. University of Georgia, College of Agricultural and Environmental Sciences, Athens, Georgia, USA.

Rynk, R. 1992. On-farm composting handbook. 186 p. Northeast Regional Agricultural Engineering Service, Cooperative Extension Service, Ithaca, New York, USA.

Rynk, R. 2003. The art in the science of compost maturity. Compost Science \& Utilization 11:94-95.

Short, J.R., D.S. Fanning, M.S. McIntosh, J.E. Foss, and J.C. Paterson. 1986. Soils of the mall in Washington, D.C. Soil Science Society of America Journal 50:699705.

Scharenbroch, B.C., J.E. Lloyd, and J.L. JohnsonMaynard. 2005. Distinguishing urban soils with physical, chemical and biological properties. Pedobiologia 49:283-296.

Tognetti, C., M.J. Mazzarino, and F. Laos. 2007. Improving the quality of municipal organic waste compost. Bioresource Technology 98:1067-1076.

Unsal, T., and S.S. Ok. 2001. Description of characteristics of humic substances from different waste materials. Bioresource Technology 78:239-242.

USDA-NRCS. 1999. Soil quality test kit guide. Infiltration test. p. 7-9. United States Department of Agriculture, Agricultural Research Service, Natural Resources Conservation Service, Washington, D.C., USA.

Vetterlein, J., and D. Hüttl. 1999. Can applied organic matter fulfill similar functions as soil organic matter? Risk benefit analysis for organic matter application as a potential strategy for rehabilitation of disturbed ecosystems. Plant and Soil 213:1-10.

Walter, I., F. Martínez, and G. Cuevas. 2006. Plant and soil responses to the application of composted MSW in a degraded, semiarid shrubland in central Spain. Compost Science \& Utilization 14:147-154.

Weber, J., A. Karczewska, J. Drozd, M. Licznar, S. Licznar, E. Jamroz, and A. Kocowicz. 2007. Agricultural and ecological aspects of a sandy soil as affected by the application of municipal solid waste composts. Soil Biology and Biochemistry 39:1294-1302. 
Zhang, M., D. Heaney, E. Solberg, and B. Heriquez. 2000. The effect of MSW compost on metal uptake and yield of wheat, barley and canola in less productive farming soils of Alberta. Compost Science \& Utilization 8:224-236.
Zucconi, F., and M. De Bertoldi. 1987. Compost specifications for the production and characterization of compost from municipal solid waste. p. 30-50. In De Bertoldi, M., M.P. Ferranti, P. L’Hermite, F. Zucconi (eds.) Compost: Production, quality and use. Elsevier Applied Science, Essex, UK. 